\title{
Hubungan Kadar TSH Terhadap Kadar FT4 Pada Pasien Tiroid Di Bangkalan
}

\author{
Ellies Tunjung S.M. ${ }^{1)}$ \\ Prodi DIII Teknologi Laboratorium Medik Universitas Muhammadiyah Surabaya \\ 1) elliestunjungismail@gmail.com
}

Tanggal Submit: 19 April 2018

Tanggal Review: 21 Mei 2018

Tanggal Publish Online:

25 Mei 2018

\begin{abstract}
Thyroid disorder disease ranks second most in the list of metabolic diseases after diabetes mellitus (DM). Thyroid disease or Thyroid abnormalities is a condition of abnormalities in a person due to the disorder of the thyroid gland. TSH is a primary factor that controls thyroid cell growth and synthesis also thyroid hormone secretion. TSH secretion is stimulated by low levels of T3 and T4 and by the hormone TRH (Thyroid Releasing Hormone) the hypothalamus is inhibited by elevated levels of T3 and T4. T3 and T4 are circulating in the plasma, most of which are bound with proteins, Thyroid Binding Globulin (TBG) and a small part in free form that are Free Triiodotironine (FT3) and Free Thyroxine (FT4). The free hormone (FT3 and FT4) is an actively metabolic fraction which is known to be quantitative. Currently the measurement of free hormone levels should be part of a complete examination of the status of the thyroid gland.

The purpose analyzes the levels of TSH, FT4 and proves the relationship between the two in patients with thyroid disorders. This examination by using ELISA method is with EIA competitive principles and sandwiches. The samples are serum of patients with thyroid disorders at RSUD Bangkalan and Farmalab Laboratory from October to November 2017.

The 30 samples obtaines an average result of TSH level of $1.9 \mathrm{mIU} / \mathrm{L}$ and an average FT4 level of $2.8 \mathrm{ng} / \mathrm{dl}$. Next test Kolmogorov-Smirnov and Spearrman's test results obtained if the variable one value rose (high) then the other variable down (low). It can be concluded that there is an opposite relationship between TSH levels and FT4 levels, if TSH levels increase, the FT4 level decreases, and so it is also in contrast
\end{abstract}

Keywords: TSH, FT4, thyroid disorders

\section{PENDAHULUAN}

Penyakit gangguan tiroid menempati urutan kedua terbanyak dalam daftar penyakit metabolik setelah diabetes mellitus (DM).
Perempuan lebih banyak menderita penyakit tiroid dibandingkan lakilaki. Prevalensi hipotiroid di Indonesia belum diketahui secara pasti. Riset Kesehattan Dasar 
(Riskesdas) 2007 melakukan pemeriksaan kadar TSH sebagai salah satu penunjang diagnostic gangguan tiroid (Pusat Data Kemenkes RI, 2015).

Penyakit atau kelainan tiroid adalah suatu kondisi kelainan pada seseorang akibat adanya gangguan kelenjar tiroid, baik berupa perubahan bentuk maupun perubahan fungsi. Dua kelainan fungsional utama pada tiroid yaitu pembentukan hormon tiroid yang berlebihan (Hipertiroidisme) dan defisiensi produksi hormon (Hipotiroidisme) (Crosby dkk, 2016).

Kelenjar tiroid mensekresi tiroksin dan triyodotironin, yang mempunyai efek nyata pada kecepatan metabolism tubuh. Kekurangan atau kehilangan hormone tirois akan menyebabkan penurunan laju metabolisme tubuh dan sekresi tiroksin yang berlebihan dapat menyebabkan laju metabolism basal meningkat (Wibowo, 2013). Kelenjar tiroid merupakan organ khusus terbesar untuk fungsi endokrin dalam tubuh manusia (Neal, 2005).

Thyroid Stimulating Hormone (TSH), merupakan hormon glikoprotein, disekresi oleh hipofisis anterior (Hardjoeno dkk, 2003). TSH merupakan faktor primer yang mengendalikan pertumbuhan sel tiroid dan sintesis serta sekresi hormon tiroid, TSH utuh ditemukan dalam serum. Kadar serum dari TSH adalah sekitar 0,5-5 mU/L meningkat pada hipotiroidisme dan menurun pada hipertiroidisme, baik karena endogen ataupun akibat asupan hormon tiroid per oral berlebihan. TSH menstimulasi penyerapan iodida dari aliran darah dan mestimulasi sintesis tiroglobulin. Selain itu TSH juga menstimulasi sintesi sodium iodine sympoter (NIS) yang yang berfungsi untuk mengiodisasi tiroglobulin membentuk hormon tiroid. Residu tirosin di tiroglobulin pada membran apikal akan mengalami iodinasi yang dikatalis oleh TPO dan $\mathrm{H}_{2} \mathrm{O}_{2}$ selanjutnya dua pasangan iodotirosin akan bergabung membentuk T4 dan T3. Selain itu TSH juga menstimulasi penyerapan folikel tiroglobulin dan sekresi hormon tiroid pada darah. Tiroglobulin yang teriodisasi akan diserap kembali ke sel folikel melewati membran apical dan akan terdegradasi membentuk 
T3/T4 pada lisosom, kemudian T3/T4 ini akan disekresikan pada membran basal (Wibowo dkk, 2013).

Kelenjar tiroid mensekresi dua hormon teriodinasi yang disebut Triiodotironin (T3) dan Tiroksin (T4) yang bertanggungjawab untuk pertumbuhan, perkembangan, fungsi dan pemeliharaan jaringan tubuh yang optimal (Neal, 2005). Hormon tiroid unik karena mengandung 59$65 \%$ unsur iodin. Tironin yang diiodinisasi diturunkan dari iodinisasi cincin fenolik dari residu tirosin dalam triglobulin membentuk mono dan diiodotirosin, yang digabungkan membentuk T3 atau T4 (Sylvia dkk, 2006).

Sekresi TSH dirangsang oleh kadar T3 dan T4 yang rendah dan oleh hormon TRH (Thyroid Releasing Hormone) hipotalamus dan dihambat oleh kenaikan kadar T3 dan T4. Jika salah satu komponen dalam segitiga hipotalamushipofisis-tiroid rusak akan mengakibatkan produksi T3 dan T4 berkurang (hipotiroidisme) atau berlebihan (hipertiroidisme)

(Hardjoeno dkk, 2003).

Hormon Thyroksine (T4) dan mempengaruhi seluruh sel organ tubuh. T3 dan T4 yang bersirkulasi dalam plasma yang sebagian besar diikat dengan protein, Thyroid Binding Globulin (TBG) dan sebagian kecil dalam bentuk bebas yaitu Free Triiodotironine (FT3) dan Free Thyroxine (FT4). Hormon yang bebas (FT3 dan FT4) merupakan fraksi yang aktif secra metabolik perlu diketahui secara kuantitatif. Hormon yang terikat dan yang bebas berada dalam keseimbangan reversibel (Hardjoeno dkk, 2003). T3 dan T4 yang tidak terikat atau bebas berinteraksi dengan reseptor intrasel dan akhirnya menyebabkan peningkatan metabolisme karbohidrat dan lemak serta meangsang sintesis protein pada beragam tipe sel (Kumar, 2007). Saat ini pengukuran kadar hormon bebas sudah menjadi bagian dari pemeriksaan yang terinci terhadap tiroid. Pengukuran T3 bebas (FT3/ Free Triiodotironine) atau $\mathrm{T} 4$ bebas (FT4/ Free Tetraiodotironine) secara langsung sulit dilakukan karena jumlah keduanya sangat sedikit yaitu $0,04 \%$ dari T4 dan 0,4\% dari T3 (Ronald dkk, 2004).
Triiodotironine

ini 
Tes fungsi tiroid bertujuan untuk membantu menentukan status tiroid. Saat ini pengukuran kadar hormon bebas harus merupakan bagian dari pemeriksaan status kelenjar tiroid yang lengkap. Kadar TSH serum mencerminkan kelenjar hipofisis anterior yang memantau kadar dari FT4 sirkulasi. Kadar FT4 yang tinggi mensupresi TSH dan FT4 yang rendah meningkatkan pelepasan TSH (Ronald, 2004).

Penelitian fungsi tiroid masih diperlukan mengingat data yang terbatas. Fungsi tiroid pada variabel penelitian ini menggunakan TSH dan free $\mathrm{T} 4$.

\section{METODE PENELITIAN}

Jenis penelitian yang digunakan adalah penelitian deskriptif dengan rancangan observasional laboratorium yang bersifat cross secsional dengan analisa data secara korelasi.

Penelitian dilakukan di RSUD Bangkalan dan Farmalab. Penelitian dilaksanakan pada bulan OktoberDesember 2017. Populasi penelitian ini adalah pasien yang terdiagnosis gangguan tiroid di RSUD Bangkalan dan Farmalab selama bulan Oktober
-Desember 2017. Sampel dari penelitian diambil 30 responden yang memenuhi kriteria sampel yaitu: pasien laki-laki dan perempuan, pasien dengan usia 3055 tahun, pasien yang terdiagnosis gangguan tiroid.

Metode pengumpulan data penelitian dilakukan secara observasional laboratorium dengan analisa data. Bahan pemeriksaan ini adalah serum pasien gangguan tiroid. Metode yang digunakan adalah ELISA (Enzyme-linked immunosorbent assay).

\section{Pemeriksaan TSH, persiapan} pasien: dianjurkan untuk tidak mengkonsumsi obat-obatan yang mengandung Iodium dan obat-obatan yang dapat mempengaruhi hasil tes, persiapan sampel: sampel serum dapat disimpan selama 4 hari pada suhu $2-8^{\circ} \mathrm{C}, 30$ hari pada suhu $-20^{\circ} \mathrm{C}$, prinsip pemeriksaan TSH (Sanwich): TSH dalam spesimen direaksikan dengan monoclonal anti TSH antibodi dalam jumlah berlebihan yang terikat pada dinding fase padat (well). Enzim konjugat berlabel anti TSH dalam jumlah berlebihan ditambahkan untuk membuat ikatan kuat dalam waktu 
dan suhu tertentu. Enzim berlabel anti TSH yang tidak terikat dipisahkan dengan cara dicuci. Substrat ditambahkan untuk membentuk produk cromogen yang berwarna biru (berisi sampel, standart, control, anti TSH, konjugat, substrat) dalam waktu dan suhu tertentu. Dengan penambahan larutan penyetop yang bersifat asam, reaksi dihentikan dan warna akan berubah menjadi kuning. Intensitas warna yang terjadi sebanding dengan kadar TSH dan diukur melalui absorban pada panjang gelombang $450 \mathrm{~nm}$.

Alat yang digunakan yaitu Immunoanalyzer, Pipet volumetrik dan Well, reagen yang digunakan adalah reagen TSH kit.

\section{Prosedur pemeriksaan}

TSH, sebanyak $50 \quad \mu l$ standart,control,serum test dimasukkan ke dalam well, ditambahkan $100 \mu$ l konjugat warna merah, digoyang 20 detik dan ditutup dengan paraffin. Kemudian diinkubasi 60 menit pada suhu 20$25^{\circ} \mathrm{C}$, lalu dibuang larutan kemudian dicuci 5 kali dengan $300 \mu \mathrm{l}$ larutan pencuci (WASH), sisa larutan dituang dengan membalik platel pada tissue, kemudian ditambahkan $100 \mu \mathrm{l}$
SUB, digoyang 20 detik, diinkubasi 15 menit pada suhu $20-25^{\circ} \mathrm{C}$ (Hindarkan dari cahaya), ditambahkan $100 \mu \mathrm{l}$ STOP, lalu digoyang 20 detik dan ukur absorban pada 450 \& $630 \mathrm{~nm}$, pemeriksaan dilakukan dalam waktu 30 menit. Nilai Normal : 0,4-6,2 mIU/l

Pemeriksaan FT4, pasien tidak memerlukan persiapan khusus, persiapan sampel: sampel yang digunakan serum. Sampel dapat digunakan dalam 48 jam pada $2-8^{\circ} \mathrm{C}$, 30 hari pada $-20^{\circ} \mathrm{C}$, prinsip pemeriksaan FT4 (Kompetitif EIA): FT4 dalam specimen dan T4 dalam konjugat direaksikan dengan anti T4 dalam jumlah berlebihan yang terikat pada dinding fase padat (microwell) secara kompetitif. Anti T4 yang tidak terikat setelah diinkubasikan kemudian dipisahkan dengan cara dicuci. Substrat ditambahkan untuk membentuk produk chromogen yang berwarna biru (berisi sampel, standart, control, anti T4, konjugat, substrat) dalam waktu dan suhu tertentu. Dengan penambahan larutan penyetop yang bersifat asam, warna akan berubah menjadi kuning dan diukur pada panjang gelombang $450 \mathrm{~nm}$, alat: 
Immunoanalyzer, pipet volumetrik dan Well dan reagen yang digunakan adalah reagen FT4 kit.

\section{Prosedur pemeriksaan FT4:}

dimasukkan $50 \mu \mathrm{l}$ standart, control, serum test ke dalam well, ditambahkan $100 \mu$ l konjugat warna hijau, digoyang 20 detik, ditutup dengan parafilm, diinkubasi 60 menit $20-25^{\circ} \mathrm{C}$, larutan dibuang, kemudian dicuci 3 kali dengan $300 \mu$ l larutan pencuci (WASH), sisa larutan dibuang dengan membalik plate pada tissue, ditambahkan $50 \mu \mathrm{l} \mathrm{SA}+50 \mu 1$ SB, digoyang 20 detik, diinkubasi 15 menit pada $20-25^{\circ} \mathrm{C}$, hindarkan dari cahaya, setelah diinkubasi, tambahkan $50 \quad \mu l$ STOP lalu digoyang 20 detik, absorban diukur pada 450 \& $630 \mathrm{~nm}$, pemeriksaan dilakukan dalam waktu 10 menit. Nilai normal, dewasa: $1,4(0,8-2,0)$ ng / dl dan wanita hamil: $1,5(0,8-$ 2,2) ng /dl.

\section{HASIL DAN PEMBAHASAN}

Penelitian diikuti oleh 30 pasien dengan subyek laki-laki dan perempuan, rerata umur 30-55 tahun. Selanjutnya dilakukan pemeriksaan kadar TSH dan FT4 pada pasien tiroid di Bangkalan.
Tabel 3.1. Hasil Kadar TSH dan FT4

\begin{tabular}{|c|c|c|}
\hline $\begin{array}{c}\text { No. } \\
\text { Pasien }\end{array}$ & TSH (mIU/L) & FT4 (ng/dl) \\
\hline 1. & 2.0 & 1.1 \\
\hline 2. & 1.4 & 1.0 \\
\hline 3. & 0.9 & 0.8 \\
\hline 4. & 3.3 & 16.0 \\
\hline 5. & 1.6 & 0.9 \\
\hline 6. & 1.2 & 1.3 \\
\hline 7. & 0.5 & 1.2 \\
\hline 8. & 18.0 & 1.0 \\
\hline 9. & 1.7 & 1.2 \\
\hline 10. & 3.7 & 1.4 \\
\hline 11. & 0.5 & 1.2 \\
\hline 12. & 2.4 & 1.1 \\
\hline 13. & 1.1 & 1.1 \\
\hline 14. & 1.1 & 16.0 \\
\hline 15. & 2.7 & 1.1 \\
\hline 16. & 1.2 & 1.3 \\
\hline 17. & 2.9 & 0.9 \\
\hline 18. & 0.8 & 1.7 \\
\hline 19. & 0.4 & 1.5 \\
\hline 20. & 0.2 & 1.5 \\
\hline 21. & 1.0 & 18.0 \\
\hline 22. & 0.8 & 1.2 \\
\hline 23. & 1.3 & 1.0 \\
\hline 24. & 1.7 & 1.2 \\
\hline 25. & 0.5 & 1.4 \\
\hline 26. & 1.5 & 1.3 \\
\hline 27. & 0.7 & 1.5 \\
\hline 28. & 0.8 & 3.6 \\
\hline 29. & 0.5 & 1.2 \\
\hline 30. & 0.6 & 1.4 \\
\hline
\end{tabular}

Berdasarkan tabel 3.1 hasil pemeriksaan kadar Thyroid Stimulating Homone (TSH) dapat dilihat hasil yang bervariasi. Nilai yang paling rendah/batas bawah nilai normal adalah $0,2 \mathrm{mIU} / \mathrm{L}$ dan nilai tertinggi adalah 18,0 mIU/L dengan nilai normal $0,4-6,2 \mathrm{mIU} / \mathrm{L}$, hasil pemeriksaan kadar Free Thyroxine (FT4) dapat dilihat hasil yang bervariasi. 
Nilai yang paling rendah/batas bawah nilai normal adalah $0,8 \mathrm{ng} / \mathrm{dl}$ dan nilai tertinggi adalah $18,0 \mathrm{ng} / \mathrm{dl}$ dengan nilai normal $0,8-2,0 \mathrm{ng} / \mathrm{dl}$.

Dari tabel hasil pemeriksaan yang telah diperoleh, dapat digambarkan dengan grafik :

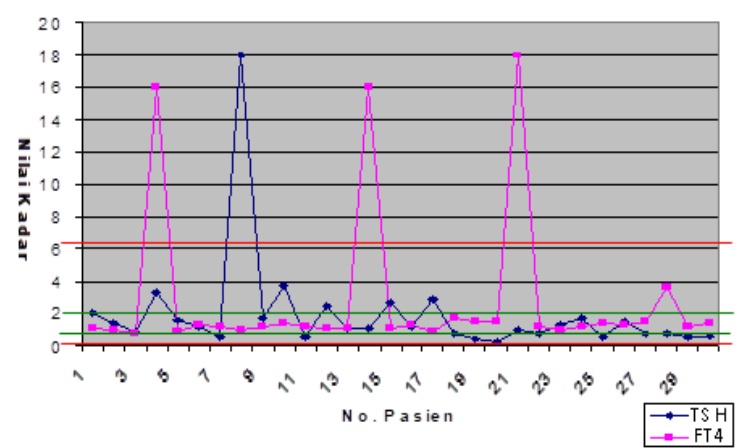

Gambar 3.1 Grafik hasil pemeriksaan kadar Thyroid Stimulating Hormone (TSH) dan Free Thyroxine (FT4)

Sesuai dengan hasil diatas dan setelah dilakukan analisa data didapatkan bahwa data kadar TSH dan kadar FT4 tidak berdistribusi normal sehingga dapat dilanjutkan dengan uji statistik yaitu uji korelasi Spearman's. Dari uji statistik korelasi Spearman's diperoleh bahwa ada hubungan antara kadar TSH dengan kadar FT4, korelasi yang terjadi adalah hubungan berlawanan arah yang artinya apabila variabel satu nilainya naik maka variabel yang lain nilainya turun, yaitu apabila kadar TSH naik maka kadar FT4 turun dan begitu sebaliknya.

Mekanisme hormonnya yaitu hormon Tiroksine

(T4) dan

Triiodotironine

ini mempengaruhi seluruh sel organ tubuh. T3 dan T4 yang bersirkulasi dalam plasma yang sebagian besar diikat dengan protein, Thyroid Binding Globulin (TBG) dan sebagian kecil dalam bentuk bebas (Free Triiodotironine/FT3 dan Free Thyroxine/FT4). Hormon yang bebas (FT3 dan FT4) merupakan fraksi yang aktif secara metabolik perlu diketahui secara kuantitatif. Hormon yang terikat ini merupakan hormon glikoprotein, disekresi oleh hipofisis anterior. Sekresi TSH dirangsang oleh kadar T3, T4, FT3 dan FT4 yang rendah oleh hormon TRH (Thyroid Releasing Hormone) hipotalamus. Sedangkan TSH akan dihambat/disupresi oleh kenaikan kadar T3, T4, FT3 dan FT4, ini sesuai dengan pernyataan Hardjoeno pada tahun 2003.

Berdasarkan hasil pemeriksaan didapatkan hasil kadar TSH yang tinggi disertai penurunan kadar FT4, kadar TSH rendah disertai peningkatan kadar 
FT4,tetapi didapatkan pula hasil kadar TSH normal disertai peningkatan kadar FT4, kadar TSH tinggi tetapi kadar FT4 normal,serta kadar kedua-duanya dalam batas normal. Apabila kadar TSH tinggi, kadar FT4 rendah maka pasien mengalami hipotiroidisme, jika kadar FT4 rendah dan kadar TSH tinggi maka pasien mengalami hipertiroidisme. Keadaan tersebut dipengaruhi oleh asupan iodium dalam tubuh yang nantinya masuk ke dalam kelenjar tiroid. Sedangkan kemungkinan-kemungkinan lainnya yaitu kadar TSH normal tetapi FT4 tinggi, kadar TSH tinggi tetapi kadar FT4 normal bisa terjadi akibat kerusakan dan pengaruh dari organ atau kelenjar lainnya.

Keberhasilan penelitian tergantung pula pada perlakuan sampel yang akan digunakan yaitu serum yang tidak lisis dan lipemik, serum yang beku hanya boleh dicairkan satu kali saja, menghindari kotaminasi dan pemipetan spesimen yang dilakukan hanya dalam waktu 10 menit. Juga tergantung pada ketelitian dari setiap peneliti di laboratorium.
Setelah

dilakukan pemeriksaan dan sebelum dilakukan uji statistik, perlu dilakukan uji kenormalan data. Untuk mengetahui data berdistribusi normal atau tidak dilakukan uji kenormalan dengan menggunakan uji KolmogorovSmirnov.

Dari hasil uji KolmogorovSmirnov didapat $\operatorname{Sig}(\mathrm{P})$ untuk kadar $\mathrm{TSH}=0,011$ untuk $\operatorname{Sig}(\mathrm{P})$ untuk kadar FT4 $=0,000$ pada $\alpha=0,05$. Pada kadar TSH Sig(P) 0,011< < 0,05 maka hipotesis nol ditolak, artinya : data tidak berdistribusi normal. Pada kadar FT4 Sig(P) 0,000 pada $\alpha 0,05$, karena $\mathrm{P} 0,000<$ a 0,05 maka hipotesis nol ditolak, artinya : data tidak berdistribusi normal.

Karena data tidak berdistribusi normal maka uji korelasi yang digunakan adalah korelasi Spearman's untuk mengetahui ada tidaknya hubungan antara kadar TSH dengan kadar FT4 pada penderita gangguan tiroid.

Dari hasil uji didapat hasil 0,386 signifikan pada $\alpha=0,05$ nilai ini mendekati -1 berarti korelasi yang terjadi cukup $(>0,25-0,5)$. Tanda negatif pada koefisien 
korelasi hanya menunjukkan bahwa hubungan yang terjadi berlawanan arah, artinya apabila variabel satu nilainya naik(tinggi) maka variabel yang lain turun (rendah).

\section{KESIMPULAN}

Berdasarkan analisa data dan pembahasan dapat diperoleh :

1. Hasil pemeriksaan kadar Thyroid Stimulating Hormone (TSH) dengan nilai rata-ratanya $1,9 \mathrm{mIU} / \mathrm{L}$

2. Hasil pemeriksaan kadar Free Thyroxine (FT4) dengan nilai rata-ratanya $2,8 \mathrm{ng} / \mathrm{dl}$

3. Terdapat hubungan antara kadar Thyroid Stimulating Hormone (TSH) dengan kadar Free Thyroxine (FT4). Hubungan yang terjadi adalah berlawanan arah yang artinya apabila variabel satu nilainya naik maka variabel yang lain nilainya turun yaitu apabila kadar Thyroid Stimulating Hormone (TSH) tinggi maka kadar Free Thyroxine (FT4) rendah/batas bawah normal dan apabila kadar Thyroid Stimulating Hormone (TSH) rendah/batas bawah normal maka kadar Free Thyroxine (FT4) tinggi.

\section{DAFTAR PUSTAKA}

Wibowo, A. dan Samsudin, M., 2013, Hubungan Kadar Tiroglobulin, TSH dan fT4 serum Pada Anak Usia Sekolah Di Tiga Kabupaten Dengan Tingkat Endemitas Defisiensi-Iodium Berbeda, Penelitian Gizi dan Makanan, Vol.36 (1): 12-19).

Pusat Data dan Informasi Kemenkes RI, 2015, International Thyroid Awareness Week, ISSN 2442-7659).

Crosby, H., Pontoh, V. dan Merung, M,A., 2016, Pola kelainan tiroid di RSUP Prof.Dr.R.D Kandou Manado periode Januari 2013Desember 2015, Jurnal eClinic volume 4, Nomor 1 .

Neal, M, J., 2005, At a Glance Farmakologi Medis Edisi Kelima Erlangga Medicine Series.

Sylvia, A., Trice, Wilson, L, M., 2006, Patofisiologi Konsep Klinis Proses Proses Penyakit, Edisi 6 Volume 2, EGC, Jakarta.

Hardjoeno, 2003, Interpretasi Hasil Tes Laboratorium Diagnostik, LEPHAS, Makasar. 
Ronald, A., Sacher, Macpherson, 2004, Tinjauan Klinis Hasil Pemeriksaan Laboratorium Edisi II, EGC, Jakarta.

Kumar, Vinay, 2007, Buku Ajar Patologi Robbins, volume 2, EGC, Jakarta. 